\title{
Peranan industri sub sektor perhotelan terhadap penyerapan tenaga kerja di Provinsi Jambi
}

\author{
*Christina Maya Lestari; Zulfanetti; Dearmi Artis \\ Prodi Ekonomi Pembangunan, Fakultas Ekonomi dan Bisnis, Universitas Jambi \\ *E-mail korespondensi: mayalestari43@gmail.com
}

\begin{abstract}
This study aims to determine the effect of Number of Hotels, Number of Rooms, Room Occupancy Rates, Minimum Wages on employment opportunities in Hotels in Jambi Province. This study uses an Ordinary Least Squares (OLS) multiple regression analysis model.Based on the results of the regression analysis, it is known that the variable number of hotels and minimum wages has a significant effect on the level of employment in Jambi Province, while the variable number of rooms and occupancy rates have no significant effect on the employment of industrial labor in the hotel subsector in Jambi Province.

Keywords: Number of Hotels, Number of Rooms, Occupancy Rate, Minimum Wage, Absorption of Labor.

Abstrak

Penelitian ini bertujuan antara lain untuk mengetahui pengaruh Jumlah Hotel, Jumlah Kamar, Tingkat Hunian Kamar, Upah Minimum terhadap kesempatan kerja pada Hotel di Provinsi Jambi. Penelitian ini menggunakan model analisis metode regresi berganda Ordinary Least Squares (OLS). Berdasarkan hasil analiss regresi diketahui bahwa variabel Jumlah Hotel dan Upah Minimum berpengaruh signifikan terhadap tingkat tenaga kerja di Provinsi Jambi sedangkan Variabel Jumlah kamar dan tingkat hunian tidak berpengaruh signifikan terhadap penyerpan tenaga kerja industri sub sektor perhotelan di Provinsi Jambi.
\end{abstract}

Kata Kunci: Jumlah Hotel, Jumlah Kamar, Tingkat Hunian, Upah Minimum, Penyerapan Tenaga kerja.

\section{PENDAHULUAN}

Sub sektor perhotelan adalah salah satu sub sektor yang memiliki peranan penting dalam penyerapan tenaga kerja di Indonesia, terutama di Provinsi Jambi saat ini sudah banyak sekali investor membangun hotel di sejumlah titik kota maupun kabupaten yang juga memiliki tempat wisata di Provinsi Jambi. Yang diharap sangat berperan dalam penyerapan tenaga kerja dan mengurangi tingkat pengangguran, tidak terlepas juga dari sektor pendukung seperti sektor pariwisata. Sektor pariwisata sendiri juga memiliki peran penting dalam perekonomian, sebagai salah satu sumber penerima devisa maupun penciptaan peluang kesempatan kerja, serta kesempatan berusaha. Sebagai Provinsi yang belum cukup banyak memiliki pesona wisata, Provinsi Jambi terus mengupayakan perubahan dan penggalian, baik dalam sisi alamiah maupun wisata buatan. Karena sebenarnya Provinsi Jambi memiliki tempat-tempat yang potensial sebagai tempat pariwisata (Sumarsono, 2003).

Untuk meningkatkan kesejahteraan rakyat, pengembangan pariwisata perlu dilanjutkan dan ditingkatkan melalui perluasan, pemanfaatan sumber dan potensi pariwisata nasional, sehingga diharapkan mampu mendorong dan menggerakan sektorsektor ekonomi lainnya (Heriawan, 2004). 
Provinsi Jambi memiliki objek wista yang cukup dan beragam yang tersebar dibeberapa Kabupaten, jenis wisata yang dapat dikunjungi di Jambi adalah wisata seperti: Kersik Tuo di Kabupaten Kerinci, Danau Kaco di Kabupaten Kerinci, Air Terjun Sungai Medang di Kabupaten Sarolangun, Air Terjun Kolam Jodoh di Kabupaten Merangin, Air Terjun Segerincing di Merangin, Air Terjun Dukun Bertuah, Air Terjun Sungai Besar di Kabupaten Bungo dan masih banyak lainnya. Peningkatan jumlah wisatawan mancanegara yang datang perlu diimbangi dengan peningkatan fasilitas dan sarana penunjang kepariwisataan seperti jumlah kamar, maupun akomodasi lainnya (Disbudpar Jambi, 2013).

Ketenagakerjaan merupakan aspek mendasar dalam kehidupan manusia karena mencakup dimensi sosial dan ekonomi salah satu tujuan penting dalam pembangunan ekonomi. Penyediaan lapangan kerja yang cukup untuk mengejar pertumbuhan angkatan kerja yang pertumbuhannya kebih cepat dari pertumbuhan kesempatan kerja (Todaro, 2000).

Berdasarkan paparan di atas maka yang menjadi rumusan masalah dalam penelitian ini adalah: (1) Bagaimana perkembangan penyerapan tenaga kerja pada industri sub sektor perhotelan di Provinsi Jambi; (2) Bagaimana perkembangan Jumlah hotel, Jumlah kamar, Tingkat Hunian, Upah minimum terhadap penyerapan tenaga kerja sub sektor industri perhotelan di Provinsi Jambi; (3) Bagaimana pengaruh Jumlah Hotel, Jumlah Kamar, Upah Minimum terhadap penyerapan tenaga kerja industri sub sektor perhotelan di Provinsi Jambi.

\section{METODE}

Data yang digunakan dalam penelitian ini adalah data sekunder runtut waktu (Time Series) pada rentan waktu tahun 2001-2016 dengan pertimbangan ketersediaan data. Data yang digunakan dalam rumusan masalah ini adalah sebagai berikut: Data Jumlah Tenaga Kerja yang berkerja di Hotel di Provinsi Jambi, Data Jumlah Hotel di Provinsi Jambi, Data Jumlah Kamar pada Hotel di Provinsi Jambi, Data Tingkat Hunian Hotel di Provinsi Jambi, Data Upah Minimum Provinsi Jambi. Untuk menemukan pemecahan masalah yang ditemukan dan membuktikan hipotesis, maka metode analisis yang digunakan analisis regresi berganda dengan menggunakan persamaan regresi berganda sebagai berikut:

$\mathrm{Y}=\boldsymbol{\beta}+\beta_{1} \mathrm{X}_{1}+\beta_{2} \mathrm{X}_{2}+\beta_{3} \mathrm{X}_{3}+\beta_{4} \mathrm{X}_{4}+\mathrm{et}_{\mathrm{t}}$

Dimana:

$\mathrm{Y}=$ Jumlah penyerapan tenaga kerja pada hotel

$\beta \quad=$ Bilangan konstanta

$\beta_{1}, \beta_{2}, \beta_{3}, \beta_{4} \quad=$ Koefisien regresi pada hotel

$\mathrm{X}_{1} \quad=$ Jumlah hotel

$\mathrm{X}_{2} \quad=$ Jumlah kamar

$\mathrm{X}_{3} \quad=$ Tingkat hunian

$\mathrm{X}_{4} \quad=$ Upah minimum

et $\quad=$ Simpangan baku

\section{Pengujian Asumsi Klasik \\ Uji Heteroskedasitas}

Heteroskedastisitas adalah varian dari residual model regresi yang digunakan dalam penelitian tidak homokedastis atau dengan kata lain tidak konstan. Data yang diambil dari pengamatan satu ke lain atau data yang diambil dari observasi satu ke yang lain tidak memiliki residual yang 63 konstan atau tetap. Untuk menguji ada tidaknya 
heteroskedastisitas dilakukan dengan menguji residual hasil estimasi menggunakan metode Harvey dengan membandingkan nilai Obs*R Square ( ) dengan nilai Chi-square ( ). Jika nilai Chi-square yang di dapatkan melebihi nilai Chi-square kritis pada tingkat signifikansi yang dipilih, kesimpulannya adalah terdapat heterokedastisitas. Jika nilainya tidak melebihii nilai Chi-square kritis, tidak terdapat heterokedastisitas (Gujarati, 2010).

- $\mathrm{H}_{0}: \mathrm{X}^{2}>\mathrm{X}^{2}$, model mengalami masalah heteroskedastisitas.

- $\mathrm{H}_{a}: \mathrm{X}^{2}<\mathrm{X}^{2}$, model terbebas dari masalah heteroskedastisitas.

\section{Uji Autokorelasi}

Autokorelasi adalah keadaan dimana faktor-faktor pengganggu yang satudengan yang lain tidak saing berhubungan. Pengujian terhadap gejala autokorelasi dilakukan dengan pengujian Breusch-Godfrey Serial Correlation LM Test dengan membandingkan nilai Obs*R Square dengan nilai Chi-square (Gujarati, 2010).

- $\mathrm{H}_{0}: \mathrm{X}^{2}>\mathrm{X}^{2}$, model mengalami masalah autokorelasi.

- $\mathrm{H}_{a}: \mathrm{X}^{2}<\mathrm{X}^{2}$, model terbebas dari masalah autokorelasi.

\section{Uji Multikolinearitas}

Multikolinearitas berari keberadaan dari hubungan linear yang "sempurna", atau tepat, di antara sebagian atau seluruh variabel penjelas dalam sebuah model regresi. Pengujian terhadap gejala multikolinearitas dapat dilakukan dengan menghitung Variance Inflation Factor (VIF) dari hasil estimasi. Semakin besar nilai VIF, variabel $\mathrm{Xi}$ akan semakin"bermasalah" atau semakin kolinear. Sebagai suatu aturan baku, jika nilai VIF suatu variabel melebihi 10 , yang akan terjadi di mana jika nilai $\mathrm{R}_{2}$ melebihi 0,90 variabel tersebut dikatakan sangat kolinear. Kecepatan dari meningkatnya varians atau kovarians dapat dilihat dengan Variance Inflation Factor (VIF), yang didefinisikan sebagai berikut:

$$
\mathrm{VIF}=\frac{1}{\left(\begin{array}{c}
r^{2}{ }^{3} \\
2
\end{array}\right)}
$$

Seiring dengan $r_{23}^{2}$ mendekati 1 , VIF mendekati tidak terhingga. Hal tersebut menunjukkan sebagaimana jangkauan kolinearitas meningkat, varian dari sebuah estimator juga meningkat, dan pada suatu nilai batas dapat menjadi tidak terhingga (Gujarati, 2010).

- $\mathrm{H}_{0}:$ VIF $>10$, terdapat multikolinearitas antar variabel bebas.

- $\mathrm{H}_{a}: \mathrm{VIF}<10$, tidak ada multikolinearitas antar variabel bebas.

\section{Uji Normalitas}

Uji normalitas adalah uji yang dilakukan untuk mengetahui apakah residual terdistribusi normal atau tidak. Pengujian normalitas dilakukan 62 dengan uji JarqueBera (JB). Pengujian ini diawali dengan menghitung skewness (kemiringan) dan kurtosis (keruncingan) yang mengukur residual OLS dan menggunakan pengujian statistik (Gujarati, 2010). 
- $\mathrm{H}_{0}$ : JB statistik $>\mathrm{X}^{2}$, p-value $>10 \%$, residual terdistribusi dengan normal.

- $\mathrm{H}_{a}$ : JB statistik $<\mathrm{X}^{2}, p$-value $<10 \%$, residual tidak terdistribusi dengan normal.

\section{Pengujian Hipotesis}

$\mathbf{U j i}-\mathbf{T}$

Uji t dilakukan untuk melihat hubungan atau pengaruh antara variabel bebas secara individual terhadap variabel terikat (Gujarati, 2010).

Dengan kriteria pengujian sebagai berikut:

- Jika $\mathrm{t}_{\text {hitung }}<\mathrm{t}_{\text {tabel }}$, maka diterima dan $\mathrm{H}_{a}$ ditolak, artinya variabel bebas tidak berpengaruh terhadap variabel terikat.

- Jika $\mathrm{t}_{\text {hitung }}>\mathrm{t}_{\text {tabel }}$, maka $\mathrm{H}_{0}$ ditolak dan $\mathrm{H}_{a}$ diterima, artinya variabel bebas berpengaruh terhadap variabel terikat.

\section{Uji - F}

Pengujian ini akan memperlihatkan hubungan atau pengaruh antara variabel independen secara bersama-sama terhadap variabel dependen (Gujarati, 2010).

Hipotesis hotel yang digunakan adalah sebagai berikut:

- $\mathrm{H}_{0}: \beta_{t}=0$, secara bersama-sama variabel bebas tidak berpengaruh signifikan terhadap variabel terikat.

- $\mathrm{H}_{a}: \beta_{t} \neq 0$, secara bersama-sama variabel bebas tidak berpengaruh signifikan terhadap variabel terikat.

Dengan kriteria pengujian yang digunakan adalah sebagai berikut:

- Jika $\mathrm{F}_{\text {hitung }}<\mathrm{F}_{\text {tabel }}$, maka $\mathrm{H}_{0}$ diterima dan $\mathrm{H}_{a}$ ditolak, artinya seluruh variabel bebas tidak berpengaruh terhadap variabel terikat.

- Jika $\mathrm{F}_{\text {hitung }}>\mathrm{F}_{\text {tabel }}$, maka $\mathrm{H}_{0}$ ditolak dan $\mathrm{H}_{a}$ diterima, artinya seluruh variabel bebas berpengaruh terhadap variabel terikat.

\section{Koefisien Determinasi $\left(\mathbf{R}^{2}\right)$}

Untuk melihat dan mengetahui besarnya sumbangan variabel independent terhadap variabel dependen, maka digunakan analisis varian dengan perhitungan determinasi dengan menggunakan model sebagai berikut (Damodar Gujarati, 1999):

$\mathrm{R}^{2}=\mathrm{r}^{2}$ X 100

Dimana: $\mathrm{R}^{2}=$ Koefisien determinasi

$\mathrm{R}=$ Nilai koefisien korelasi

Nilai $\mathrm{R}^{2}$ ini menunjukkan seberapa besar variabel independent mampu menjelaskan variabel dependent. Kemudian untuk melihat keeratan hubungan antara variabel independent dengan variabel dependent dilakukan dengan mengambil akar dari $\mathrm{R}^{2}$ sehingga di dapat $\mathrm{R}$ yang semakin rendah mendekati 1 menandakan bahwa hubungan antara variabel independent dengan variabel dependent semakin erat.

\section{HASIL DAN PEMBAHASAN}

\section{Perkembangan tenaga kerja pada hotel di Provinsi Jambi}

Tenaga kerja pada Hotel sendiri adalah tenaga kerja yang memberikan jasa pelayanan pada tamu. Tenaga kerja itu sendiri terdiri dari berbagai banyak bagian pada 
hotel, baik dalam jabatan tertinggi maupun jabatan terendah (Marpaung, 2002). Perkembangan hotel di Provinsi Jambi setiap tahun terus meningkat baik itu hotel berbintang maupun non bintang. Serupa dengan penelitian yang dilakukan Probo Sansoko (2014) sektor hotel dan restoran memiliki peranan penting terhadap penyerapan tenaga kerja di Kabupaten Mojokerto, hal ini dilihat dari menigkatnya jumlah usaha akomodasi perhotelan dikabupaten Mojokerto di tiap tahunnya, oleh karena itu permintaan tenaga kerja terus meningkat. Yang diharapkan dapat meningkatkan taraf hidup masyarakat. Untuk melihat perkembangan tenaga kerja yang berkerja pada Hotel di Provinsi Jambi dapat dilihat pada tabel 1 berikut ini:

Tabel 1. Perkembangan jumlah tenaga kerja pada hotel di Provinsi Jambi

\begin{tabular}{ccc}
\hline Tahun & Tenaga kerja (jiwa) & Perkembangan (\%) \\
\hline 2001 & 1.334 & - \\
2002 & 1.345 & 0,82 \\
2003 & 1.010 & $-24,9$ \\
2004 & 1.375 & 3,31 \\
2005 & 1.572 & 1,43 \\
2006 & 1.556 & $-0,10$ \\
2007 & 1.272 & $-1,81$ \\
2008 & 1.661 & 3,05 \\
2009 & 1.861 & 1,20 \\
2010 & 1.911 & 0,26 \\
2011 & 2.171 & 1,36 \\
2012 & 2.345 & 0,80 \\
2013 & 2.463 & 0,50 \\
2014 & 2.734 & 1,20 \\
2015 & 2.698 & $-0,13$ \\
2016 & 2.701 & 0,11 \\
\hline \multicolumn{3}{c}{}
\end{tabular}

Sumber: Badan Pusat Statistik Provinsi Jambi, 2016 (diolah)

Berdasarkan pada Tabel.1 bahwa jumlah tenaga kerja yang berkerja pada industri sub sektor perhotelan pada tahun 2001-2016 rata-rata perkembangannya adalah sebesar 6,20 persen. Adapun jumlah tenaga kerja tertinggi tercatat pada tahun 2016 yakni sebanyak 2.701 dengan tingkat perkembangan yakni sebesar 0,11 persen.

Tingkat perkembangan tertinggi pada tahun 2004 yakni 3.31 dengan jumlah tenaga kerja yakni sebanyak 1.375 jiwa. Hal ini dikarenakan hotel adalah suatu industri padat karya, dan pembangunan tidak terjadi setiap tahun, dalam proses pembangunan hotel sendiri akan banyak digunakan tenaga kerja khususnya laki-laki dalam proses pembangunan, akan memberi kesempatan kerja, dan akan meningkatkan taraf hidup masyaraakat dan mengurangi kemiskinan.

\section{Perkembangan jumlah hotel di Provinsi Jambi}

Industri sub sektor perhotelan merupakan rangkuman dari berbagai macam bidang usaha yang secara bersama-sama menghasilkan produk-produk maupun jasa pelayanan atau service yang nantinya baik langsung atau tidak langsung akan dibutuhkan wisatawan. Namun seiring perkembangan zaman kegunaan hotel tidak untuk menginap saja, akan tetapi sekarang hotel menjadi tempat untuk suatu kegiatan seperti pertemuan bisnis, seminar, musyawarah nasional dan kegiatan lainnya. 
Namun tidak sedikit banyak hotel sudah banyak tidak beroperasi yang diakibatkan dari persaingan dengan hotel-hotel berbintang yang mengakibatkan banyak hotel tutup, atau juga dengan kondisi lain seperti hotel terbakar dan terpaksa putus hubungan kerja dengan karyawan, sebagian dari pemilik. Untuk mengetahui tingkat perkembangan Jumlah Hotel di Provinsi Jambi dapat dilihat pada Tabel 2 berikut ini:

Tabel 2. Perkembangan jumlah hotel di Provinsi Jambi

\begin{tabular}{ccc}
\hline Tahun & Jumlah Hotel (bangunan) & Perkembangan(\%) \\
\hline 2001 & 59 & - \\
2002 & 69 & 16,9 \\
2003 & 58 & $-15,9$ \\
2004 & 71 & 22,4 \\
2005 & 70 & $-1,4$ \\
2006 & 70 & 1,14 \\
2007 & 47 & $-37,3$ \\
2008 & 69 & 46,8 \\
2009 & 67 & $-2,89$ \\
2010 & 67 & 1,49 \\
2011 & 75 & 10,2 \\
2012 & 72 & -4 \\
2013 & 77 & 6,95 \\
2014 & 76 & $-1,9$ \\
2015 & 75 & 2,63 \\
2016 & 85 & 13,3 \\
\hline
\end{tabular}

Sumber: Badan Pusat Statistik Provinsi Jambi, 2016 (diolah)

Dalam kurun waktu tahun 2000-2016 perkembangan Jumlah Hotel menurut Kabupaten dan Kota di Provinsi Jambi cendrung mengalami naik turun dengan rataata perkembangan yakni 3,90 persen. Peningkatan Jumlah Hotel tertinggi pada tahun 2004 sebesar 71 Hotel dengan peningkatan sebesar 22,4 persen dari tahun sebelumnya. Hal ini disebabkan banyaknya pembangunan hotel berbintang dengan kualitas yang baik dan memuaskan tingkat pengunjung pada hotel.

\section{Perkembangan jumlah kamar pada hotel di Provinsi Jambi}

Jumlah kamar adalah suatu usaha yang menggunakan bangunan atau sebagai dari padanya yang khusus disediakan, dimana setiap orang dapat menginap dan makan serta memperoleh pelayanan dan fasilitas lainnya dengan pembayaran yang berbeda, sesuai dengan tingkat kualitas pada kamar. Untuk mengetahui tingkat perkembangan Jumlah Kamar pada Hotel di Provinsi Jambi dapat dilihat pada Tabel 3 berikut ini:

Tabel 3. Perkembangan jumlah kamar pada Hotel di Provinsi Jambi

\begin{tabular}{ccc}
\hline Tahun & Jumlah kamar (unit) & Perkembangan (\%) \\
\hline 2001 & 984 & - \\
2002 & 1.156 & 17,47 \\
2003 & 1.140 & $-1,38$ \\
2004 & 1.160 & 1,75 \\
2005 & 1.145 & $-98,85$ \\
2006 & 1.145 & 0 \\
2007 & 8.15 & $-91,85$
\end{tabular}




\begin{tabular}{rrr}
2008 & 1.142 & 40,12 \\
2009 & 1.112 & $-98,88$ \\
2010 & 1.174 & 5,57 \\
2011 & 1.290 & 9,88 \\
2012 & 1.189 & $-7,82$ \\
2013 & 1.324 & 11,35 \\
2014 & 1.263 & $-4,6$ \\
2015 & 1.278 & 1,18 \\
2016 & 1.419 & 11,03 \\
\hline Rata-rata & & $\mathbf{- 1 3 , 6 6}$
\end{tabular}

Sumber: Badan Pusat Statistik Provinsi Jambi, 2016 (diolah)

Perkembangan Jumlah kamar pada Hotel selama tahun 2001-2016 rata-rata sebesar -13,6 persen. Perkembangan jumlah kamar yang mengalami peningkatan yakni pada tahun 2002 yakni sebanyak 1156 unit dan perkembangannya sebesar 17,47 persen, dan tahun-tahun berikutnya juga mengalami penurunan yang tidak baik yakni pada tahun 2006 dengan perkembangan yakni 0 persen.

\section{Perkembangan tingkat hunian kamar di Provinsi Jambi tahun 2001-2016}

Tingkat Hunian adalah suatu keadaan sampai sejauh mana kamar terjual, dengan tersedianya kamar hotel yang memadai. Para wisatawan tidak segan untuk, berkunjung ke suatu daerah. Untuk melihat perkembangan tingkat hunian kamar dapat dilihat pada tabel 4 berikut ini:

Tabel 4. Perkembangan tingkat hunian kamar di Provinsi Jambi

\begin{tabular}{ccc}
\hline Tahun & Tingkat Hunian(\%) & Perkembangan(\%) \\
\hline 2001 & 31,3 & - \\
2002 & 32,1 & $-67,9$ \\
2003 & 31,42 & $-68,58$ \\
2004 & 30,12 & $-69,88$ \\
2005 & 36,28 & 19,92 \\
2006 & 30,46 & $-69,54$ \\
2007 & 36,87 & 21,04 \\
2008 & 39,07 & $-60,93$ \\
2009 & 37,39 & $-62,61$ \\
2010 & 36,28 & $-63,72$ \\
2011 & 33,37 & $-66,63$ \\
2012 & 38,79 & $-61,21$ \\
2013 & 34,2 & $-65,8$ \\
2014 & 34,13 & $-65,87$ \\
2015 & 33,79 & $-66,21$ \\
2016 & 30,42 & $-69,58$ \\
\hline Rata rata & & $-\mathbf{5 4 , 5}$ \\
\hline
\end{tabular}

Sumber: Badan Pusat Statistik Provinsi Jambi, 2016 (diolah)

\section{Perkembangan upah minimum Provinsi Jambi tahun 2001-2016}

Upah merupakan kompensasi yang diterima oleh satu unit usaha tenaga kerja berupa jumlah uang yang divayarkan kepadanya. Adanya kebijakan pemerintah dalam penetapan upah seperti dalam penetapan Upah Minimum Provinsi (UMP) sangat diharapkan mampu mengatasi permasalahan. 
Pendapatan upah minimum tersebut diarahkan kepada pencapaian kehidupan yang layak dan ditetapakn oleh Gubernur dengan memperhatikan rekomendasi dari dewan Pengupahan Provinsi dan Bupati/Walikota (Pasal 89 UU n0.13/2003). Effciency Wage Theory menyatakan bahwa upah yang tinggi akan mendorong para perkerja untuk giat berkerja (meningkatkan produktifitas). Dengan kata lain upah yang tinggi perusahaan dapat meningkatkan kualitas rata-rata karyawan, untuk melihat tingkat perkembangn upah minimum Provinsi Jambi dapat dilihat pada Tabel 6 berikut ini:

Tabel 5. Perkembangan upah minimum Provinsi Jambi

\begin{tabular}{ccc}
\hline Tahun & Upah minimum(rupiah) & Perkembangan(\%) \\
\hline 2001 & 245.000 & - \\
2002 & 304.000 & 24,08 \\
2003 & 390.000 & 28,29 \\
2004 & 425.000 & 15,18 \\
2005 & 485.000 & 14,12 \\
2006 & 563.000 & 16,08 \\
2007 & 658.000 & 16,87 \\
2008 & 724.000 & 10,03 \\
2009 & 850.000 & 10,5 \\
2010 & 900.000 & 12,5 \\
2011 & 1.028 .000 & 14,22 \\
2012 & 1.142 .000 & 11,14 \\
2013 & 1.300 .000 & 13,79 \\
2014 & 1.502 .000 & 15,56 \\
2015 & 1.710 .000 & 13,83 \\
2016 & 1.906 .000 & 11,5 \\
\hline Rata-rata & & $\mathbf{1 4 , 7 6}$
\end{tabular}

Sumber: Badan Pusat Statistik Provinsi Jambi, 2016 (diolah)

\section{Uji Asumsi Klasik}

Uji Autokorelasi

Menurut Firdaus (2011) autokolerasi merupakan gangguan pada fungsi regresi yang berupa kolerasi diantara faktor gangguan. Kolerasi dapat terjadi di serangkaian pengamatan dari data yang diperoleh pada suatu waktu tertentu, data tersebut bisa saja data seksi silang (cross section) atau data yang diurutkan menurut waktu (time series). Untuk menguji ada tidaknya autokolerasi adalah dengan LM test. Caranya apabila yaitu nilai Prob.chi-squere lebih kecil dari 0,10 $(\alpha=10 \%)$ maka tidak ada masalah autokolerasi. Dari perhitungan menggunaka eviews didapatkan hasil Prob.Chisquere dalam penelitian ini adalah 0.1922 lebih kecil dari $0,10(\alpha=10 \%)$ maka tidak ada masalah autokolerasi.

Untuk menguji ada tidaknya autokolerasi adalah dengan LM test. Caranya apabila yaitu nilai Prob.chi-squere lebih kecil dari 0,10 $(\alpha=10 \%)$ maka tidak ada masalah autokolerasi. Dari perhitungan menggunaka eviews didapatkan hasil Prob.Chisquere dalam penelitian ini adalah 0.1922 lebih kecil dari 0,10 $(\alpha=10 \%)$ maka tidak ada masalah autokolerasi. 
Tabel 6. Hasil uji autokorelasi

\section{Breusch-Godfrey Serial Correlation LM Test:}

\begin{tabular}{llll} 
F-statistic & 1.076676 & Prob. F(4,7) & 0.4356 \\
Obs*R-squared & 6.094373 & Prob. Chi-Square(4) & 0.1922 \\
\hline
\end{tabular}

Sumber: Data diolah, 2019

Untuk menguji ada tidaknya autokolerasi adalah dengan LM test. Caranya apabila yaitu nilai Prob.chi-squere lebih kecil dari 0,10 $(\alpha=10 \%)$ maka tidak ada masalah autokolerasi. Dari perhitungan menggunaka eviews didapatkan hasil Prob.Chisquere dalam penelitian ini adalah 0.1922 lebih kecil dari 0,10 $(\alpha=10 \%)$ maka tidak ada masalah autokolerasi.

\section{Uji Multikolinearitas}

Multikolinearitas merupakan salah satu model asumsi klasik yang melihat hubungan antara sesama variabel bebas. Pengujian multikolinearitas ini menggunakan metode VIF (Variance Inflation Factors). Menurut Junaidi (2015), nilai dari pengujian menggunakan VIF minimal dibawah $\alpha=10 \%$, jika pengujian lebih dari $\alpha=10 \%$ maka mengandung gejala multikolinearitas.

Tabel 7. Hasil uji multikolinearitas

\begin{tabular}{clcc}
\hline Variable & $\begin{array}{l}\text { Coefficient } \\
\text { Variance }\end{array}$ & $\begin{array}{c}\text { Uncentered } \\
\text { VIF }\end{array}$ & $\begin{array}{c}\text { Centered } \\
\text { VIF }\end{array}$ \\
\hline C & 0.213027 & 137.0642 & NA \\
JH & 0.000199 & 621.7366 & 9.342461 \\
JK & $8.57 \mathrm{E}-07$ & 766.0497 & 9.925692 \\
THH & $1.14 \mathrm{E}-09$ & 7.157660 & 1.146359 \\
UMP & $1.42 \mathrm{E}-14$ & 9.387275 & 2.238620 \\
\hline
\end{tabular}

Sumber: Data diolah, 2019

Hasil VIF pada ke empat variabel dalam penelitian ini tidak mengandung multikolinearitas dimana VIF jumlah hotel sebesar $9.324461<\alpha=10 \%$ berarti jumlah hotel tidak menggandung multikolinearitas. VIF jumlah kamar sebesar $9.925692<\alpha=$ $10 \%$ berarti jumlah kamar tidak mengandung multikolinearitas. VIF tingkat hunian sebesar $1.146359<\alpha=10 \%$ berarti tingkat hunian tidak mengandung multikolinearitas. VIF upah minimum sebesar $2.238620<\alpha=10 \%$ berarti upah minimum tidak mengandung multikolinearitas. Dapat disimpulkan bahwa pengujian ini bebas dari gejala multikolinearitas.

\section{Uji Heteroskedasitas}

Heteroskedasitas adalah varian dari residual model regresi yang yang bertujuan untuk menguji apakah dalam model regresi terjadi ketidaksamaan dari residual suatu pengamatan ke pengamatan lainnya, cara untuk mendeteksi ada atau tidaknya heteroskedasitas dapat dilakukan menggunakan uji White test dengan cara apabila nilai Prob-Chi Square besar dari 0,10 $(\alpha=10 \%)$ maka tidak ada masalah heteroskedasitas.

Untuk menguji ada tidaknya heteroskedasitas dilakukan dengan menguji residual hasil estimasi menggunakan Harvey dengan membandingkan nilai Obs* $\mathrm{R}$ Square dengan nilai Chi-square. Dari perhitungan menggunaka eviews didapatkan hasil Prob. Chisquere dalam penelitian ini adalah 0,3320 lebih besar dari 0,10 ( $\alpha=10 \%)$ maka tidak ada masalah heteroskedasitas. 
Tabel 8. Hasil uji heteroskedasitas

\section{Heteroskedasticity Test: White}

\begin{tabular}{llll} 
F-statistic & 3.753946 & Prob. F(14,1) & 0.3862 \\
Obs*R-squared & 15.70124 & Prob. Chi-Square(14) & 0.3320 \\
Scaled explained SS & 8.573838 & Prob. Chi-Square(14) & 0.8573 \\
\hline
\end{tabular}

Sumber: Data diolah, 2019

Untuk menguji ada tidaknya heteroskedasitas dilakukan dengan menguji residual hasil estimasi menggunakan Harvey dengan membandingkan nilai Obs*R Square dengan nilai Chi-square. Dari perhitungan menggunaka eviews didapatkan hasil Prob.Chisquere dalam penelitian ini adalah 0,3320 lebih besar dari 0,10 ( $\alpha=10 \%)$ maka tidak ada masalah heteroskedasitas.

\section{Uji Normalitas}

Untuk mendeteksi apakah residualnya berdistribusi normal atau tidak dengan membandingkan nilai statistic JB dengan probability yaitu:

- Jika JB hitung < nilai probability maka data berdistribusi tidak normal.

- Jika JB hitung > nilai probability maka data berdistribusi normal.

Dari hasil perhitungan, didapatkan nilai statistic JB sebesar 1.220847 lebih besar dari nilai probability yaitu 0,543121 dengan $(\alpha=10 \%)$. Dengan nilai JB $>$ nilai probability, maka dapat disimpulkan bahwa data berdistribusi normal.

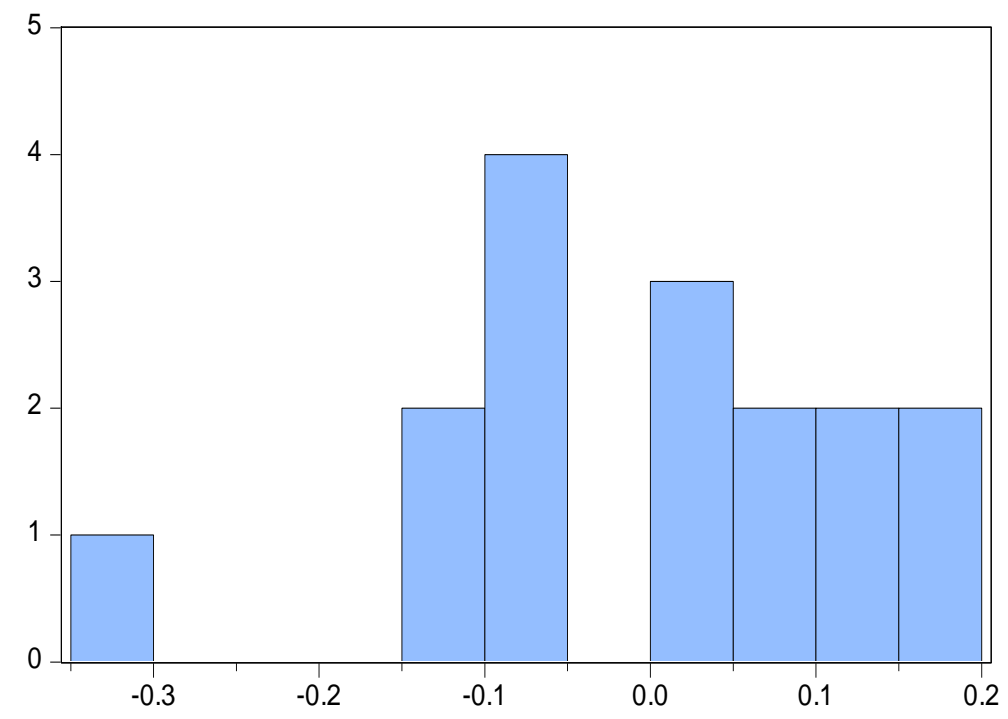

\begin{tabular}{|lc|}
\hline \multicolumn{2}{|l|}{ Series: Residuals } \\
Sample 2001 2016 \\
Observations 16 \\
Mean & $1.94 \mathrm{e}-16$ \\
Median & 0.017879 \\
Maximum & 0.185175 \\
Minimum & -0.330567 \\
Std. Dev. & 0.135041 \\
Skewness & -0.658558 \\
Kurtosis & 3.310606 \\
& \\
Jarque-Bera & 1.220847 \\
Probability & 0.543121 \\
\hline & \\
& \\
\hline
\end{tabular}

Sumber: Data diolah, 2019

\section{Kesimpulan}

Perkembangan Industri sub sektor perhotelan, jumlah hotel rata-rata 3,9 persen Perkembangan jumlah kamar rata-rata sebesar -13,66 persen. Perkembangan tingkat hunian rata-rata sebesar $-54,5$ persen dan perkembangan Upah Minimum rata-rata sebesar 14,76 persen. Variabel Jumlah Hotel dan Upah Minimum berpengaruh signifikan terhadap penyerapan tenaga kerja di Provinsi Jambi dan variabel jumlah kamar dan tingkat hunian tidak berpengaruh signifikan. 


\section{Saran}

Pemerintah Daerah diharapkan lebih memperhatikan dan meningkatkan kualitas objek wisata, guna meningkatkan minat wisatawan untuk berkunjung, khusunya usaha akomodasi sektor hotel dalam rangka menciptakan lapangan kerja bagi masyarakat di Provinsi Jambi.

Bagi peneliti-peneliti selanjutnya disarankan dapat menemukan variabel-variabel lain yang pengaruhnya lebih nyata dalam peranan industri perhotelan dalam menciptakan lapangan kerja.

\section{DAFTAR PUSTAKA}

Amir Amri., Yulmardi., Junaidi. (2009). Metodologi Penelitian Ekonomi dan Penerapannya: IPB PRESS: Bogor.

BPS Provinsi Jambi. (2001-2017). Jambi Dalam Angka.Provinsi Jambi: Jambi.

Firdaus, Muhammad. (2009). Ekonometrika: Suatu Pendekatan Aplikatif, Edisi Kedua,Cetakan Kedua, Bumi Aksara: Jakarta.

Dinas Pariwisata dan Kebudayaan Provinsi Jambi. (2013). Buku Statistik Kepariwisataan Provinsi Jambi 2013. Dalam http: https://www.google.com/search?q=dinas+kepariwisataan+provinsi+jambi\&oq=dinas+ kepariwisataan+provinsi+jambi\&aqs. 12 Januari 201914.00 WIB.

Gujarti, Damodar. (2010) Basic Econometric. Diterjemahkan oleh Sumarno Zain. Erlangga: Jakarta.

Heriawan, R. (2004). Peranan dan Dampak Pariwisata pada Perekonomian Indonesia. Institut Pertanian Bogor: Bogor.

Marpaung, H. (2002). Pengetahuan Kepariwisataan. Bandung: Alfabeta.

Probo, Sasongko., Dewie Triwijayanti. (2014). Analisis Penyerapan Tenaga Kerja Sektor Perhotelan dan Restoran di Kecamatan Pacet Kabupaten Mojokerto. Dalam jurnal ekonomi dan bisnis. Surabaya. Vol (6). 140-160.

Simanjuntak, Payaman J. (2005). Pengantar Ekonomi Sumber Daya Manusia. Jakarta: Fakultas Ekonomi Universitas Indonesia.

Sumarsono, Sony. (2003). Ekonomi Manajemen Sumber Daya Manusia dan Ketenagakerjaan. Graha Ilmu: Yogyakarta.

Todaro, Michael, P. (2002). Pembangunan Ekonomi di Dunia Ketiga. Erlangga: Jakarta. 